\title{
HESCHEL, HIDDENNESS, AND THE GOD OF ISRAEL
}

\author{
JOSHUA BLANCHARD \\ University of North Carolina at Chapel Hill
}

\begin{abstract}
Drawing on the writings of the Jewish thinker, Abraham Joshua Heschel, I defend a partial response to the problem of divine hiddenness. A Jewish approach to divine love includes the thought that God desires meaningful relationship not only with individual persons, but also with communities of persons. In combination with John Schellenberg's account of divine love, the admission of God's desire for such relationships makes possible that a person may fail to believe that God exists not because of any individual failing, but because the individual is a member of a larger community that itself is culpable.
\end{abstract}

'This is an age of spiritual blackout, a blackout of God. We have entered not only the dark night of the soul, but also the dark night of society. We must seek out ways of preserving the strong and deep truth of a living God theology in the midst of the blackout.'

'A time is coming - declares my Lord God - when I will send a famine upon the land: not a hunger for bread or a thirst for water, but for hearing the words of the Lord. Men shall wander from sea to sea and from north to east to seek the word of the Lord, but they shall not find it.'

\section{INTRODUCTION}

According to the argument from divine hiddenness, the existence of non-resistant non-believers poses a special problem for theistic religions

\footnotetext{
${ }^{1}$ Abraham Joshua Heschel, 'On Prayer', in Moral Grandeur and Spiritual Audacity, edited by Susannah Heschel (New York: Farrar, Straus, and Giroux, 1996), pp. 257-267.

${ }^{2}$ Amos 8:11-12 (Jewish Publication Society).
} 
that describe God as perfectly loving. Below I develop a response to this argument from a particular Jewish perspective, relying especially on the thought of Abraham Joshua Heschel, whose writings have not been significantly explored in contemporary analytic philosophy of religion. ${ }^{3}$ According to this perspective, God seeks meaningful personal relationships, not only with individual persons, but also with communities of persons. I claim that it is constitutive of meaningful individual relationships that members of the relationship are vulnerable in certain ways to the actions and attitudes of those with whom they are related, and that the same goes for relationships with communities. This general picture helps blunt the force of the hiddenness argument, because it offers at least one kind of explanation for the existence of non-resistant non-believers that is grounded in divine love. Moreover, the combination of divine vulnerability and the nature of group relationships gives us an independently valuable form of interdependence both between human beings and between human beings and God. I do not contend that the picture developed here solves all cases of divine hiddenness, or that the argument from divine hiddenness does not still somewhat reduce the probability of traditional theisms. I contend more modestly that these considerations should at least be part of any successful overall approach to the problem. ${ }^{4}$

\section{SCHELLENBERG'S ARGUMENT FROM HIDDENNESS}

J.L. Schellenberg defends by far the most thorough and powerful version of the hiddenness argument. ${ }^{5}$ One of the many interesting features of

\footnotetext{
${ }^{3}$ Recent work by Howard Wettstein provides a happy exception to this fact. See The Significance of Religious Experience (Oxford: Oxford University Press, 2012), especially chapters 5 and 7 . Wettstein writes that in earlier life he was 'too rigidly analytical to appreciate Heschel' (p. 5).

${ }^{4}$ I am offering what Dustin Crummett calls a "partial response" to the problem. See Dustin Crummet, 'We Are Here To Help Each Other', Faith and Philosophy, 32:1 (2015), pp. 45-62.

${ }^{5}$ Less-developed arguments that trade on similar themes can be found elsewhere, e.g. Walter Sinnott-Armstrong's 'Argument from Ignorance' in William Lane Craig and Walter Sinnott-Armstrong's God? A Debate Between a Christian and an Atheist (New York: Oxford University Press, 2004), pp. 101-105. Sinnott-Armstrong writes, 'If there were an all-good and all-powerful God who could act in time, then we would have better evidence than we have. He could easily reveal himself by appearing before us. Giving us better evidence would not harm us. Why would such a God hide?' (p. 104).
} 
the argument is the specificity of its target, relative to the more general target of more well-known theistic and atheistic arguments. Schellenberg rightly implores philosophers of religion to philosophically reflect on a conception of God that is more authentic and particular to the religious life than bare classical theism, and it is this focus that makes the problem of divine hiddenness especially salient.

Here is a brief (and simplified) summary of how Schellenberg poses his puzzle to an enriched theism. In addition to the classical omni-properties (e.g., omnipotence, omniscience, and omnibenevolence), many religious persons and traditions attribute to God the property of perfect love. Schellenberg plausibly conceives of perfect love as including a desire for and openness to significant consensual relationships with persons. 'God, if loving, seeks explicit, reciprocal relationship with us, involving not only such things as Divine guidance, support, and forgiveness, but also human trust, obedience, and worship.' That God merely 'seeks' and does not necessarily achieve such relationships is essential to the argument. Schellenberg rightly acknowledges that God must respect the autonomous human rejection of such relationship, so that 'a loving God, out of respect for our freedom, might well allow us to shut him out

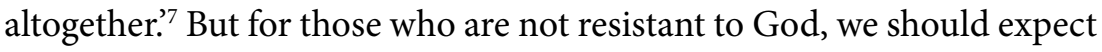
God to be open to an 'explicit, reciprocal' relationship. Thus, the only thing standing between a non-resistant person and actually entering into a relationship with God is that person's own initiation. Any non-resistant non-believing person who tries to enter into relationship with God will be successful.

How does belief enter the picture? It is plausible that propositional belief that God exists is a necessary condition for the robust kind of relationship just described. This is not to deny that there are relational values in the neighbourhood that are non-doxastically available to us. Like many philosophers, I think that faith, rightly understood, is one such value. ${ }^{8}$ One non-doxastic way to understand faith is as a kind of volitional, practical, and hopeful attachment to something, whether it be a person or ideal. There may be less robust forms of relationship to God

\footnotetext{
${ }^{6}$ John Schellenberg, Divine Hiddenness and Human Reason (Ithaca, NY: Cornell University Press, 2006), p. 18.

${ }^{7}$ Schellenberg, Divine Hiddenness, p. 27.

${ }^{8}$ See Daniel Howard-Snyder, 'Does Faith Entail Belief?', Faith and Philosophy, 33:2 (2016), 142-162, for a fairly comprehensive scepticism regarding the view that faith requires belief. Thanks to Terrence Cuneo for pointing me to this paper.
} 
(and other persons) available to those who have this kind of non-doxastic faith. However, I agree with Schellenberg that it is difficult to imagine how explicit, reciprocal relationship involving support, obedience, worship and Schellenberg's several other desiderata could occur without belief that God exists. So I prefer to take on board Schellenberg's necessary condition on relationship. That being said, even supposing that some people are able to enter into this robust kind of relationship with God via non-doxastic faith, it is not very plausible that there is no one for whom lack of belief is a decisive barrier to relationship with God. Though it is not always noticed, the problem of divine hiddenness remains a challenge for theists even if belief is not always a necessary condition for relationship with God. Even if belief is a necessary condition for at least some non-believer's belief in God, hiddenness poses a problem.

Given the conjunction of some belief condition and Schellenberg's analysis of a perfectly loving God, theism predicts that non-resistant non-believers who try but fail to enter into relationship with God simply do not exist. ${ }^{9}$ In virtue of exhibiting perfect love alongside the other omni-properties, God would only permit non-belief in cases of either resistance or failure to enter into a relationship with God. Unfortunately for theism, however, it seems overwhelmingly probable that non-resistant non-believers of the relevant sort do exist, disconfirming theism. ${ }^{10}$

${ }^{9}$ In order to accommodate the weaker belief condition above (that for at least one non-resistant person, lack of belief that God exists is a decisive barrier to relationship with God), 'non-resistant non-believers' can be modified as, 'non-resistant persons who lack relationship with God.' Alternatively, we could read 'non-believer' as a person who lacks either the belief or non-doxastic faith required for robust relationship. For simplicity's sake, I retain Schellenberg's formulation throughout.

${ }^{10}$ One option for responding to Schellenberg's argument, popular in certain theological circles, is to deny the existence of non-resistant non-belief altogether, instead claiming either (1) that everyone at bottom believes in God; or (2) that although some people do not believe in God, every such person at bottom is in a state of resistance. Such a view combines an extravagantly bold claim regarding the psychologies of nearly everyone who ever lived (that they are either believers or resistant non-believers), plus a massive discounting of innumerable individuals' testimonies about their own psychology and experience. And so while I am happy to agree that this is a metaphysically possible explanation of divine hiddenness, I do not think it is a very epistemologically tenable one. But see Paul Moser's The Elusive God: Reorienting Religious Epistemology (Cambridge: Cambridge University Press, 2008) for an interesting development of a view like this. According to Moser, God would only reveal God's self to persons who are appropriately attuned or oriented toward receiving evidence from a person such as God - and this attunement includes fairly specific traits like humility and openness to 
And so it is that the adoption of a richer, more authentic theism results in vulnerability to the following argument from divine hiddenness ${ }^{11}$ :

(1) If God exists, then God is perfectly loving toward persons. [Premise]

(2) If God is perfectly loving toward persons, then God is open to being in an explicit, reciprocal relationship with non-resistant persons. [Premise]

(3) If God exists, then God is open to being in an explicit, reciprocal relationship with non-resistant persons. [From 1 and 2]

(4) If God is open to being in an explicit, reciprocal relationship with non-resistant persons, then no non-resistant non-believers, who try but fail to enter into relationship with God, exist. [Premise]

(5) If God exists, then no non-resistant non-believers, who try but fail to enter into relationship with God, exist. [From 3 and 4]

(6) There is at least one non-resistant non-believer who tries but fails to enter into relationship with God. [Premise]

Therefore,

(7) It is not the case that God exists. [From 5 and 6]

Sometimes philosophers will respond to Schellenberg's argument without making explicit which steps in the argument they are bringing into question. To avoid this pitfall, let me make my strategy explicit immediately. I will be considering two aspects of a Jewish conception of God, viz. God's relational love for, and hence vulnerability to, groups of persons. Proper consideration of the nature of groups, combined with an analysis of perfect love that Schellenberg otherwise accepts, shows that premise 2 is false, because there is at least one condition in which God's openness to relationship with persons does not follow from God's perfect love for them.

total submission to God. As I understand Moser's view, most if not all non-believers count as 'resistant' in that, on his system, they must lack the requisite character traits for receiving the 'purposively available' evidence from God.

${ }^{11}$ This formulation is a simplification of what Schellenberg offers in, "Divine Hiddenness and Human Philosophy," in Hidden Divinity and Religious Belief: New Perspectives, edited by Adam Green and Eleonore Stump (Cambridge: Cambridge University Press, 2015), pp. 13-32 (pp. 24-25). 


\section{HESCHEL'S HIDDEN GOD AND COMMUNAL RESPONSIBILITY}

Abraham Joshua Heschel responded to the second World War, and the Shoah [Holocaust] in particular, partly by claiming that the community of Europe (or at least the communities within Europe responsible for the Shoah), over the course of centuries, exiled God and awareness of God from their midst.

Through centuries [God's] voice cried in the wilderness. How skillfully it was trapped and imprisoned in the temples! How thoroughly distorted! Now we behold how it gradually withdraws, abandoning one people after another, departing from their souls, despising their wisdom. The taste for goodness has all but gone from the earth. ${ }^{12}$

Heschel is not describing God as being simultaneously present and absent, or offering a diagnosis of the loss of the usefulness of the concept of God to human beings. Rather, Heschel describes this phenomenon as an actual 'exile' of God, and one that is not wholly voluntary on God's part. 'God who created the world is not at home in the world, in its dark alleys of misery, callousness and defiance. ${ }^{13}$ Surprisingly (and offensively, to classical philosophical and theological temperament), Heschel seems to intend that we take his words literally. 'God did not depart of His own volition; He was expelled. God is in exile. ${ }^{14}$ Heschel's provocative understanding of divine exile is not just an isolated device to explain God's absence; it is also an essential component in his understanding of the function of the religious life. 'Our task is to bring God back into the world, into our lives. To worship is to expand the presence of God in the world. ${ }^{15}$ Some of the specific spiritual disciplines, like prayer, serve to achieve this purpose, to welcome God back. Heschel writes, 'I pray because God, the Shekinah, is an outcast. I pray because God is in exile, because we all conspire to blur all signs of His presence in the present or in the past. ${ }^{16}$ Such excerpts are easily multiplied. At the core of Heschel's remarks on God's absence is the thought that, together and over time,

12 Abraham Joshua Heschel, Man is Not Alone (New York: Farrar, Straus, and Giroux, 1951), p. 152. Cf. Abraham Joshua Heschel, 'The Meaning of this War', in Moral Grandeur and Spiritual Audacity, edited by Susannah Heschel (New York: Farrar, Straus, and Giroux, 1996), pp. 209-212.

${ }^{13}$ Heschel, God in Search of Man, p. 156.

${ }^{14}$ Heschel, Man is Not Alone, p. 153.

${ }^{15}$ Heschel, God in Search of Man, p. 157.

${ }^{16}$ Heschel, 'On Prayer,' p. 260. 
human beings can, through both actions and omissions, remove (or help to bring back) God. ${ }^{17}$

There is more than one way to interpret and develop Heschel's conception of the communal acts that exile God. This ambiguity is due partly to the fact that Heschel's writing often aims to achieve a certain existential or phenomenological effect in the reader, sometimes at the expense of analytical clarity. ${ }^{18}$ First, perhaps every member of a community can act so as to cause God to depart from that community, the community responsible for the exiling. This interpretation closely links the victims of God's absence to an action for which they each share some responsibility. Second, perhaps some but not all members of a community can act in a way that causes God to leave the whole community. Maybe God leaves the community on account of its representative members, e.g. its religious or political leaders. Or maybe God leaves the community on account of some of its members, even if they are not representative.

As long as some but not all members of a community can exile God, then there may be innocent victims of God's absence. On all of the above interpretations, there is some link between those who suffer God's absence and those whose culpable actions cause God's absence. On one interpretation, the link is identity - the victims of God's absence just are the individuals who caused it. But on others, the link is more innocent, being either representation or shared membership. The interpretation on which every member's action contributes to God's exile might seem morally better to many philosophers than the others, at least insofar as

\footnotetext{
${ }^{17}$ See Shai Held's The Call of Transcendence (Bloomington, IN: Indiana University Press, 2013) for a thorough discussion of an ambiguity in Heschel's writings between what Held calls 'ontological' and 'epistemological' hiddenness, already evidenced even in the few passages I've referenced. Ontological hiddenness is the absence of God. Epistemological hiddenness is just the lack of human awareness of God. Held thinks that both lines of thought are present in Heschel and adopts the project of reconciling them. In this paper, I am mainly interested in the ontological stream of Heschel's thought, though both provide the theist with resources for thinking about Schellenberg's argument. Cf. Schellenberg's similar conceptual distinction between 'objective' and 'subjective' hiddenness in John Schellenberg, 'Divine Hiddenness', in A Companion to Philosophy of Religion, 2nd edition, edited by C. Taliaferro, P. Draper, and P. L. Quinn (Oxford: Blackwell, 2010), pp. 509-518 (p. 509).

${ }^{18}$ See Edward K. Kaplan, 'Heschel as Philosopher: Phenomenology and the Rhetoric of Revelation,' Modern Judaism, 21:1 (2001), on what Kaplan calls Heschel's 'phenomenological writing.'
} 
it seems more fair that God would prevent the innocent from suffering God's absence. Nevertheless, the other accounts, and in particular the one in which even non-representative members can exile God, is precisely the sort of picture that seems to animate Heschel's writings on God's relationship to the world.

These ideas complicate our picture of the relationship-oriented desires of a perfectly loving God. On Judaism as Heschel conceives it (as on many of the more 'covenantal' versions of Christianity) God does not only, or even primarily, desire and participate in relationships with individuals qua individuals. But that is not because God is non-relational or non-loving. Rather, God is also related to and loves communities, e.g. Israel (or the Church). Part of God's relationship-seeking, loving nature, on this conception, is the desire to exist in mutually helpful and morally significant relationships with communities of human beings, not just individual human beings. Just like in individual-individual relationships, individual-community relationships allow that one member may push away the other. Here is the most important point: unlike individual persons, communities can perform actions to which not all of their constitutive members have contributed or even consented. Trivially, an individual person contributes to the actions that she performs, but she need not always contribute to an action performed by a community of which she is a member, a community whose fate is nevertheless necessarily bound up with hers.

Recall that Schellenberg allows that an individual might cause God to be hidden from her own conscious life, since such a possibility is a necessary condition of a genuine, meaningful relationship between that person and God. This individual allowance does little for a theist wanting to respond to the argument from divine hiddenness, because by definition it leaves untouched the problem of non-resistant nonbelievers. But when we expand our notion of perfect love to include love of communities, we see that individuals who are, at least qua individuals, innocent of actions that drive out God, can nevertheless be caught up in the effects of the actions of related others who perform this driving out on behalf of the community. ${ }^{19}$ While this arrangement might seem somewhat unfair to many philosophers and non-philosophers alike,

${ }^{19}$ In his reading of Martin Buber, Robert Adams discovers a similar theme. According to Adams, Buber sees God's 'hiding' as '... a process in human history, a social or cultural and thus still a human fact, though perhaps not in the individual human mind ... There 
dual vulnerability - of human individuals, on the one hand, and God, on the other - is partly constitutive of a genuine, meaningful relationship between God and communities of human persons, just as it is between God and an individual.

Because God loves communities and desires relationship with them, and because these kinds of relationships are valuable, God has at least some reason to permit God's self, as well as human persons, to continue to exist in this vulnerable state. To preserve the authenticity of God's relationship to communities and God's vulnerability, it must be possible for human actions to have communal and not only individual import. If God always maintained an equally strong relationship with each nonresistant person everywhere, then the significance of God's relationship to human communities would be greatly diminished. This would not be a wholly bad state of affairs, but it would be lacking along at least one valuable dimension of human and divine experience. ${ }^{20}$

Because this dimension of human and divine experience is itself valuable, it need not only serve the purpose of thinking about divine hiddenness. This view incorporates an independently valuable picture of our moral lives that makes it appealing apart from the aid it provides us in trying to solve Schellenberg's problem. If Heschel is right, then my individual actions and state of being do not only have potential consequences for my own experience of God, but they have potential consequences for others' experiences as well. This expanded circle of moral responsibility for the spiritual wellbeing of not only myself but of others is an attractive feature of the position. ${ }^{21}$

is human responsibility, individual as well as social, for the eclipse' (Robert Adams, 'The Silence of God in the Thought of Martin Buber', Philosophia 30:1-4 (2003), 51-68 (p. 60)).

${ }^{20}$ This kind of point about relationships is not foreign to analytic philosophy of religion. Eleonore Stump, for example, defends petitionary prayer partly on the grounds that a meaningful, non-overbearing relationship involves making some of one's actions conditional on the other participant's asking for things. Because this kind of relationship is good, God has at least some reason to knowingly withhold good things from human beings in light of their not having asked for them. See Eleonore Stump, 'Petitionary Prayer,', American Philosophical Quarterly, 16: 2 (1979), 81-91. The point here is that this important insight, typically applied to individual relationships, applies to group relationships as well.

${ }^{21}$ Cf. a provocative remark by Terence Cuneo in 'Another Look at Divine Hiddenness', Religious Studies, 49 (2013), 151-164: '[I]f I understand the argument [from hiddenness] correctly, its strategy is to claim that, given what we know about the nature of love and what theists say about God and God's relationship to human beings, God would 
There is an additional way in which God's relationship to groups rather than individuals is good. Relationship to groups of human beings satisfies, in Heschel's terminology, a 'divine need'. According to Heschel, God is unwilling to be alone. ${ }^{22}$ God is also in need of human fulfilment of the commandments: 'the God of Israel is ... in need of man's integrity. ${ }^{23}$ The fact that God desires and needs relationship not only to human individuals, but to human communities as well, itself bestows some worth on those relationships. In addition to being a valuable part of human experience, these relationships are a valuable part of divine experience. Indeed, they in part motivate God to create the world. So these relationships bear some value in virtue of their satisfaction of the good desires and needs of a good being. But they in turn bear value in that it is good for us to satisfy such needs. Just as it is good to provide water for those who are thirsty, not only good for the one whose thirst is quenched but for the one who provides, it is good to provide meaningful relationships to those who lack them - not only good for the one who receives but for those who provide.

My remarks about the good of interdependence echo what has been said elsewhere in the literature on divine hiddenness under the banner of what Schellenberg calls "responsibility arguments." 24 Although the goodness of responsibility partly explains why relationships with communities are themselves good independently of explaining hiddenness, my argument is not, fundamentally, a responsibility argument. In a responsibility argument, the fact that it is good for us to be partly responsible for each other serves as God's reason for allowing non-resistant non-belief. But in my argument, it is the fact that God loves and desires relationship with communities that serves as at least one reason why God might allow non-resistant non-belief. Insofar as God

not actualize a world that included non-resisting non-believers. But if this is so, the proponent of the argument must be prepared to concede, for argument's sake, certain things that theists say about God and God's relation to human beings. Among the things that theists say is this: no one is brought into proper relationship with God, others, and the natural world alone. Your actions may abet or impede my ability to relate rightly to God, you, and the natural world. This is the theme, prominent in the Christian east, of the solidarity of salvation.' (p. 164 n. 6)

${ }^{22}$ Heschel, Man is Not Alone, p. 91.

${ }^{23}$ Heschel, Man is Not Alone, p. 245.

${ }^{24}$ See especially Schellenberg, Divine Hiddenness and Human Reason, p. 192ff; Travis Dumsday, "Divine Hiddenness and the Responsibility Argument," Faith and Philosophy, 12:2 (2010), pp. 357-371; and Crummett, "We are Here to Help Each Other". 
seeks relationship with communities, God risks communal resistance, and insofar as communities resist, their individual members are at risk of ignorance of God. Rather than a trade-off between relationship with God and other goods, my argument highlights a potential trade-off between two kinds of valuable relationship with God. ${ }^{25}$

\section{OBJECTIONS}

Some resistance to this picture may arise due to a characteristically Western emphasis on individualism and autonomy, which corresponds to a de-emphasizing of culture, community, the spirit of the age, and related phenomena that affect the religious life of individuals. On Heschel's view, while we may certainly suffer the absence of God partly due to our own individual failings, we suffer it not only due to them. As creatures embedded in multiple communities, what we experience, know, and feel is to that extent also in the hands of others. Thus I am partly responsible not only for my own attunement to experience of God, but for my neighbor's as well. But not only that. I am part of communities which themselves, qua communities, have effects on my own life.

In addition to accommodating the value of relationships with community, another advantage of this picture over a solely individualistic picture is that it accommodates much of our collective religious experience (or lack thereof), at least in the West. Charles Taylor's grand project in A Secular Age illustrates this point nicely. ${ }^{26}$ In that work Taylor charts the development of 'secularism' in his special sense, which is the new reality that most people can with relative ease envision their lives as deeply non-religious. This development serves to undercut the kind of surety and givenness of religious life and experience available in previous eras. On a very large scale, then, we can read Taylor as explaining one mechanism by which individuals' abilities to believe that God exists can be undermined by collective actions and processes which, crucially, are themselves attributable to no particular individual.

Some might worry that these sorts of pictures, and in particular Heschel's picture of a God whose presence in individual human lives is vulnerable to communal action, place an undue - indeed,

${ }^{25}$ Thanks to John Schellenberg for pointing out to me that I need to distinguish my argument from responsibility arguments.

${ }^{26}$ Charles Taylor, A Secular Age (Harvard University Press, 2007). 
unloving - burden on human beings. While it seems to me that Heschel's view does place more responsibility on us for others than what we might like, it actually mitigates our burden as individuals. Although we contribute to the cultures of the communities in which we live, as individuals we typically exercise very little direct control over them. For those non-resistant persons who do not believe, and even for those who believe but cannot believe very strongly, this explanation provides some degree of comfort. The dual appeal to communal responsibility and divine vulnerability makes one's non-belief or doubt intelligible: you fail to believe strongly or at all partly because communities in which you are embedded have failed in certain respects, or because you live in a 'secular age'. But this means that you are not especially to blame for this condition, at least not qua individual. In fact, when Heschel writes on the topic of sustaining faith, it is obvious that he does not expect most individuals to continuously experience a subjective awareness of God. Heschel writes that 'I believe' means 'I remember', and that experiences of God's presence 'are not common occurrences'. Rather,

In the lives of most people they are as meteors which flare up for a moment and then disappear from sight. There are, however, people for whom these flashes ignite with them a light which will never be extinguished. Faith means: If you ever once merit that the Hidden One appears to you, be faithful to Him all the days of your life. Faith means: To guard forever the echo which once burst upon the deep recesses of our soul. ${ }^{27}$

At least for those of us who live in an age and culture guilty of the collective failures identified by Heschel, we should not feel as if we are individually to blame for our religious malaise.

In thinking about objections to the apparent fairness of allowing individuals to suffer God's absence due to failures not necessarily their own, it is worth being reminded (as Schellenberg sometimes reminds his readers) that the argument at issue is not the argument from evil and suffering, in which context this kind of picture is less plausible. Consider a person who endures some horrendous evil; it may seem morally objectionable that God's reason for allowing this person to suffer is simply that their community is unfaithful to God in some way. Perhaps some

${ }^{27}$ Abraham Joshua Heschel, 'Pikuach Neshama: to Save a Soul', in Moral Grandeur and Spiritual Audacity, edited by Susannah Heschel (New York: Farrar, Straus, and Giroux, 1996), pp. 54-67 (p. 64). Cf. Heschel, Man is not Alone, p. 165. 
suffering can be justified like this, but it does not seem that the worst kinds and instances can be. Perhaps some readers feel an analogous resistance to this approach in the case of divine hiddenness. But when it comes to individuals merely lacking belief in God, it is at least not obviously bad that this would depend partly on the actions of the communities of which they are part. It is an open question whether other great harms come to individuals due to the communal failures that exile God. It's true that if such harms take place, then a problem for theism surfaces; but this is just the problem of suffering brought about by the means of hiddenness, not the problem of divine hiddenness itself. Provided that the phenomena of hiddenness and suffering can be separated, as I think they can be, then the objection in question is not appropriately aimed at a solution to the hiddenness problem.

The approach of this paper may elicit an additional significant objection, important enough to warrant consideration here, though far too complex to treat fully. Some traditional theists will think that the picture I have painted of Heschelian Judaism, according to which God is not only related to both individuals and groups, but is genuinely vulnerable to and in need of them, is incompatible with any philosophically acceptable version of theism. Any philosophically acceptable conception of theism, so this objection says, cannot allow that God is vulnerable or lacking in any way, because such a conception violates the necessary truth that God is perfect. If a perfect being is a being who is wholly self-sufficient and incapable of needs, then the picture sketched above is not one on which God is perfect.

As I noted at the beginning, the problem of divine hiddenness arises partly due to a sensible emphasis on taking the rich content of lived religion more seriously. This sometimes involves engaging a tapestry of values and possibilities in which philosophers' problems have often already been incorporated. Religious pictures, though often universal in their scope and application, are inherently idiosyncratic. Any attempt to raise problems for these idiosyncratic systems must take this into account. We cannot, with one hand, offer an intellectual objection to a lived religious system, yet with the other hand deprive that system of its own intellectual resources.

Furthermore, religious systems sometimes make claims not only about history, metaphysics, and applied ethics, but also about values themselves. Heschel's religion, for example, makes claims about the pervasive, radical dependency we have on each other, and the value of 
being interdependent in this way. It is part of Heschel's Judaism that it is good to be partly responsible for - to be needed for - the religious life of my neighbour, and to be needed even by God. And it is part of this Judaism that part of God's love and need is a love and need for communities, whether Israel, the nations, or the world. The objection in question presupposes that a state of interdependence of this kind is less perfect than a state of pure independence. This presupposition seems unwarranted, especially in light of the apparent goodness intrinsic to interdependent relationships.

Ultimately the best response for a thinker like Heschel to the objection in question is to say that the criticism really shows the moral and theological inadequacy of philosophical theism. ${ }^{28}$ Heschel's own writings draw a sharp distinction between the 'God of Israel' and the 'God of the philosophers'. Heschel writes, 'The God of Israel is a name, not a notion.'29 A name 'describes', whereas a notion 'evokes'. According to Heschel, a fundamental semantic difference between the Jewish and philosophical God is that the former is named as a particular 'individual', whereas the latter is whatever happens to satisfy a concept that 'applies to all objects of similar properties' - in principle, whatever being satisfies the concept counts as God. The God in whom Heschel is interested answers to concerns fundamentally different from the God of philosophy.

A first cause or an idea of the absolute - devoid of life, devoid of freedom - is an issue for science or metaphysics rather than a concern of the soul or the conscience. An affirmation of such a cause or such an idea would be an answer unrelated to our question. The living soul is not concerned with a dead cause but with a living God. Our goal is to ascertain the existence of a Being to whom we may confess our sins, of a God who loves, of a God who is not above concern with our inquiry and search for Him; a father, not an absolute. ${ }^{30}$

Human beings know God, not by 'timeless qualities', but by the 'living acts of God's concern. ${ }^{31}$ Readers may recognize here echoes of Pascal, who writes:

${ }^{28}$ In this Heschel would find allies in contemporary feminist philosophy of religion. See, e.g. Sarah Coakley, "Feminism and Analytic Philosophy of Religion", The Oxford Handbook of Philosophy of Religion, edited by William J. Wainwright (New York: Oxford University Press, 2005), pp. 494-525.

${ }^{29}$ Heschel, Man is not Alone, p. 269.

${ }^{30}$ Heschel, God in Search of Man, pp. 125-6.

${ }^{31}$ Heschel, God in Search of Man, p. 21. 
The God of Christians does not consist in a God who is merely the author of geometrical truths and of the order of the elements. ... He does not consist simply in a God who exercises his Providence over the life and property of men, so as to grant those who worship him a happy span of years. ... But the God of Abraham, the God of Isaac, the God of Jacob, the god of Christians is a God of love and consolation; he is a God who fills the soul and heart of those whom he possesses; he is a God who makes them inwardly aware of their wretchedness and his infinite mercy; who unites himself to the depths of their soul; who fills their soul with humility, joy, confidence, love; who makes them incapable of any other end but himself. ${ }^{32}$

But it is more likely that Heschel is continuing in the tradition of the medieval Jewish philosopher Judah Halevi, who likewise writes:

The philosophers' proof methodologies led them to believe in a god who neither helps nor hinders; he is not aware of our prayers or sacrifices, nor our devotion to or rebellion against them.... None of these philosophers can identify their god by its definitive name. But one who has heard God's words, commands, and admonitions, and has heard the reward for serving Him and the punishments for sinning against Him - such a person is able to call God by his definitive name, which describes the Entity that has spoken to him. ${ }^{33}$

If Schellenberg's argument from hiddenness is to challenge forms of theism beyond the usual bare theism targeted by analytic argumentation, then it must take into account the decidedly non-philosophical nature of some of the most prominent manifestations of religious life and thought. By 'non-philosophical' I do not mean 'anti-philosophical', or anything that involves the abdication of one's rational faculties. Rather, I mean that we should take into account all of the materials from religion that may or may not have been delivered by philosophical analysis. And when we do that, we see that the force of the hiddenness argument is at least mitigated by taking seriously God's desire to be in relationships with communities of persons.

32 Blaise Pascal, Pensées, trans. by Roger Ariew (Indianapolis: Hackett, 2004), S690, pp. 227-8.

${ }^{33}$ Judah Halevi, The Kuzari: In Defense of the Despised Faith, trans. by N. Daniel Korobkin (Northvale: Roman and Littlefield, 1998), 3.2-3, p. 201. 


\section{CONCLUSION}

In summary, if a loving relationship with an individual includes vulnerability to being pushed away, then there is a plausible parallel phenomenon in a loving relationship to a community. But it is also metaphysically plausible that not everyone in a community need individually contribute to the collective actions of the community of which they are part. This fact, conjoined with the great good of spiritual interdependence, provides for a Jewish (and, more specifically, Heschelian) contribution to explaining the existence of non-resistant non-believers. ${ }^{34}$

${ }^{34}$ I'd like to add Julian Stroh to the list of acknowledgements. So it would be: “Thanks to Evan Blanchard, Judy Blanchard, Scott Blanchard, Lindsay Brainard, Terence Cuneo, Caleb Harrison, Kathryn Pogin, Michael Rea, John Schellenberg, and Julian Stroh for sending me comments on this paper." 